\title{
Burroughs Wellcome: The Seminal Link between Academia and the Pharmaceutical Industry
}

\author{
Ronald P. Rubin, $\mathrm{PhD}^{*}$ \\ Department of Pharmacology \& Toxicology, Jacobs School of Medicine \& Biomedical Sciences, University at Buffalo State University of New York \\ Buffalo, New York 14214, USA \\ ${ }^{\star}$ Corresponding author: Ronald P. Rubin, PhD, Professor \& Chair (Ret.), Department of Pharmacology \& Toxicology, Jacobs School of Medicine \& Biomedical Sciences, \\ University at Buffalo State University of New YorkBuffalo, New York 14214, USA; Email: rprubin@buffalo.edu
}

Received: November 16, 2018; Accepted: November 27, 2018; Published: December 05, 2018;

\begin{abstract}
This article reviews the research carried out by outstanding scientists to underscore the significant role played by Burroughs Wellcome Research Laboratories in erasing the differences in the objectives of scientists in academia and those in industry. These enlightened policies not only markedly advanced our fund of scientific knowledge in the biomedical sciences but led to the production of drugs that were of major benefit to mankind.
\end{abstract}

\section{Introduction}

Henry S. Wellcome (1853-1936) was an American-British entrepreneur who established the Burroughs Wellcome pharmaceutical conglomerate in London with his partner Silas Burroughs in the late 1880's. Four years later, Wellcome formed a research component, which he named The Wellcome Physiological Research Laboratories. The creation of laboratories to conduct research was quite unusual in the late 1800 's, especially in association with a pharmaceutical enterprise [1-3]. When Henry Wellcome passed away in 1936, he left two legacies, his pharmaceutical company, The Wellcome Foundation and The Wellcome Trust, which distributed the financial resources for biomedical research [4].

This article will convey the company's long time commitment to research by the fact that the staff scientists highlighted herein won a share of five Nobel Prizes (see below). At the same time, as a result of its long term involvement in basic research, Burroughs Wellcome became a major factor in bridging the gap that existed between academia and the pharmaceutical industry.

\section{Sir Henry Hallett Dale (1875-1968)}

Henry Dale (Figure 1), the renowned pioneer and leader in the discipline of Physiology/ Pharmacology, was the first major recruit to join Henry Wellcome's new research initiative when he reluctantly accepted a research position at The Wellcome Research Laboratories in 1904 [5]. In those days it was unusual for a researcher at a university to give up his academic freedom to work in industry, and several colleagues advised him to decline the offer. However, Wellcome convinced Dale that he would be able to conduct basic research without concern for the business side of the organization.

Although Dale was free to select his own topics of research to investigate, Wellcome requested that Dale undertake the problem of ergot, which was marketed by the company as an abortifacient.
Wellcome's interest in ergot was in part commercially driven by the fact that Parke Davis was also marketing an ergot preparation for use in obstetrics. This competition prompted Henry Wellcome to also recruit a chemist, George Barger, whom he also encouraged to investigate ergot. Dale did not plan on ergot studies occupying a major portion of his time; however, his initial investigations into ergot properties proved to be unexpected and exciting and led him on a path that would ultimately provide the foundation for understanding the pharmacology of autonomic drugs and culminate in the awarding of the Nobel Prize.

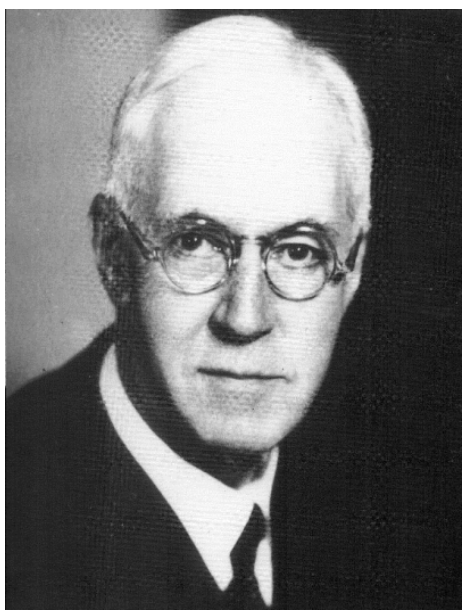

Figure 1. Sir Henry Hallett Dale ( 1875-1968)

In 1906, Dale provided the first example of an adrenergic blocking agent by demonstrating that a substance obtained from ergot called ergotoxine reversed the hypertensive effect of sympathetic nerve stimulation and epinephrine (adrenaline) [6]. The sympatholytic action of ergotoxine prompted Dale to interpret his own studies in the light of recent work by Thomas Elliott, who in 1905 observed that the action of exogenous epinephrine mimicked the effects of sympathetic 
nerve stimulation [7]. Thus, ergotoxine became important in medical history because Dale's observation that it inhibited sympathetic activity eventually led to the discovery of chemical synaptic transmission. In 1910, Dale also published a detailed account of the sympathomimetic actions of a number of biogenic amines synthesized by George Barger [8]. Unfortunately, Dale chose to exclude the epinephrine (adrenaline) series of sympathomimetics and overlooked the most physiologically relevant derivative - norepinephrine (noradrenaline) - and thus delayed for several more decades the discovery of norepinephrine as a physiological neurotransmitter.

Ergot yielded additional constituents, including histamine in 1907 and acetylcholine in 1913, although neither provided any results that could be marketed for sale. A few years later, an accidental observation made with a particular extract of ergot prompted Dale's interest in the possible existence of chemical transmission across neuronal synapses. A conventional dose of this extract caused a profound inhibition of heart rate, and was later identified as the labile substance, acetylcholine. In a paper published in 1914, Dale identified a nicotinic and muscarine-like substance in ergot as acetylcholine [9]. In this article, Dale summarizes his work by noting that "acetylcholine occurs occasionally in ergot, but its instability renders it improbable that its occurrence has any therapeutic significance [10]." Nevertheless, such findings set the stage for the classical experiments of Otto Loewi in 1921 and beyond, which provided direct evidence in favor of the theory of chemical synaptic transmission.

Thus, because of Dale's commitment to deciphering the puzzling effects of ergot, much of our knowledge of the action of autonomic drugs on the physiological components of the autonomic nervous system stems directly from the work of Henry Dale carried out at Burroughs Wellcome Research Laboratories. The quality of Dale's work was recognized by his academic peers and had much to do with reducing the prevailing negative opinion of the scientific mission of pharmaceutical companies. Dale was subsequently elected to the Royal Society and later served as President of the Royal Society of Medicine. He was knighted in 1932, and shared the Nobel Prize with Otto Loewi for a discovery of fundamental physiological significance that had its origins in a drug company interested in the pharmacological properties of ergot.

Dale spent 10 years at the Burroughs Wellcome Research Laboratories at Brockwell Park, where a great deal of his most productive work was carried out. Although Dale was appointed the first Director of the Medical Research Council at the National Institute for Medical Research in 1928, his link to Burroughs Wellcome was not at an end. In 1936, he became associated with the Trust which had been created by the will of Henry Wellcome. He first served as a Trustee, then as Chairman from 1938 to 1960 . He spent the last eight years of his life as its scientific advisor [11]. In addition, a special Henry Dale Fellowship sponsored by the Wellcome Trust provides funds for biomedical research. The basic research fostered by Henry Wellcome and implemented by Henry Dale was not only profoundly significant in its day, but it led Burroughs Wellcome to become a dominant force in biomedical research. And, it was Sir Henry Dale who set the landscape for those who were to follow.

\section{Sir John Robert Vane (1927-2004)}

John Vane (Figure 2) was considered one of Britain's most eminent pharmacologists [12]. He began working with Joshua Harold Burn at Oxford in 1946, where he learned to utilize bioassays. At the time, chemical methods were generally unavailable and bioassays, which detected and measured sensitivity of tissue strips to biologically active substances, required laborious procedures. As a graduate student, I myself toiled at a bath containing aortic strips to measure catecholamines by bioassay, and my task was made much easier when I learned the fluorometric method of assaying adrenomedullary catecholamines at Burroughs Wellcome.

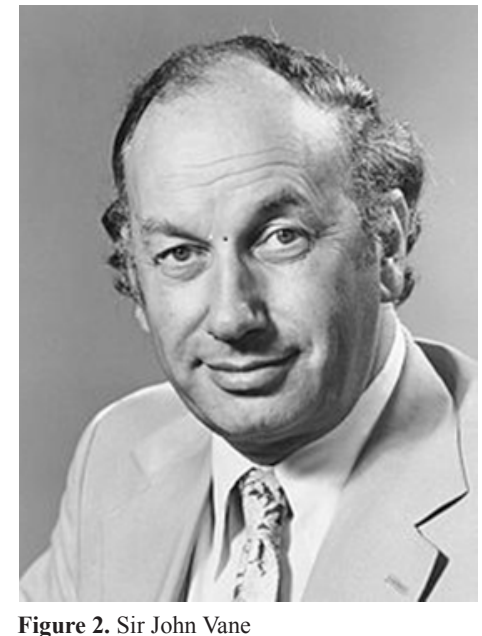

After graduating in Pharmacology and obtaining additional experience in the United States at Yale University, Vane returned to the United Kingdom where he was offered a position in The Department of Pharmacology at the University of London, which was headed by Sir William Paton. During those years, Vane, striving to move beyond outdated methodologies and antiquated concepts, further developed the blood-bathed organ bioassay system. By slowly perfusing mammalian blood over a series of isolated tissues in a cascade, Vane was able to measure the release of biologically active substances in a manner that simulated release in vivo. One of the first major biochemical processes to be discovered using the blood-bathed organ system was the conversion of angiotensin I to angiotensin II in the pulmonary vasculature. This finding led to the development of Angiotensin Converting Enzyme Inhibitors, which at the time revolutionized the treatment of hypertension. But, it was at the College of Surgeons that John Vane made an indelible mark on the scientific world by elucidating the mechanism of action of aspirin [13].

Vane left the Chair at the Royal College of Physicians in 1973, and followed the example of Henry Dale by joining The Wellcome Research Laboratories in the UK [14]. Vane, like Henry Dale, found that friends and colleagues were dubious about his accepting the offer to enter the industrial realm. Nevertheless, Vane was impressed by the fact that some seventy years before, Henry Dale had accepted a position at Burroughs Wellcome after experiencing academic life. Understanding that good science was not limited to academia, Vane undertook his new role as Director of Research and Development for a major pharmaceutical company. 
The fact that he was able to take a number of his research team with him was a major factor in his final decision, and Vane never expressed any regrets about this move. The colleagues he recruited from the Royal College of Surgeons, included Salvador Moncada, Richard Gryglewski, and Rod Flower [15].This research group composed of very talented individuals of diverse ethnic origins, backgrounds, and traditions worked together in a highly competitive research environment. Vane's laboratory became known as the Prostaglandin Research Group and served as a venue where basic pharmacological research could be carried out without being limited by outdated and narrow approaches to biomedical research. An example of the rewards that could be achieved by this philosophy was the other watershed in Vane's storied history, the discovery of prostacyclin.

The years spent at Burroughs Wellcome was a challenging period for John Vane since he assumed a new set of managerial responsibilities, as well as research goals. Imbuing colleagues with the concept that it was possible to carry out quality science in an industrial setting, Vane advised them to follow their instincts with regard to drug discovery. This concept soon reaped rewards when in 1976 the Prostaglandin Research Group under the leadership of Salvador Moncada discovered prostacyclin and elucidated its pharmacological properties by utilizing the bioassay of extracts from platelets and vascular tissues [16]. Capitalizing on the versatility of the bioassay cascade, prostacyclin was found to be the main product of arachidonic acid metabolism in arteries and veins and its major effect was to inhibit platelet aggregation by stimulating adenylate cyclase.

John Vane presided over an environment in which there was a strong interaction with academia and the pharmaceutical industry. He, like Henry Dale, clearly demonstrated how it was possible to conduct quality scientific research in an industrial setting. During those years, Vane was awarded several honors, including Fellowship in the Royal Society, The Lasker Prize, and in 1982 the Nobel Prize for Medicine [17]. Salvador Moncada, who was also involved in the discovery of nitric oxide, was considered by some as deserving of a share of the Nobel Prize [18].

The work carried out by John Vane and his associates at the Wellcome Foundation spawned important research around the world that provided additional insights into the key factors that regulate blood circulation. In 1993, after much more information was accumulated about prostacyclin, Vane eventually reached the conclusion that the endothelium occupied a key role in regulating blood circulation and that prostacyclin, as well as nitric oxide, was responsible for defending against atherosclerotic angiopathies [19].

One of Vane's other major contributions was to promote the link between scientists at academic institutions with those in the pharmaceutical industry, and he did a great deal to blur the boundaries that had separated these two groups of research scientists. In 1985, Vane returned to academia by establishing the William Harvey Research Institute at the Medical College of St. Bartholomew's Hospital, where his research group focused its attention on cyclooxygenase-2 inhibitors and the interplay between nitric oxide and endothelin in the regulation of vascular function [20].

\section{Sir James Whyte Black (1924- 2010)}

The Nobelist, James Black (Figure 3), was one of the first scientists who utilized "rational design" for discovering new drugs [21,22]. Much of Black's early work was carried out at the now defunct Imperial Chemical Industries (ICI Pharmaceuticals) in the United Kingdom from 1958-1964. Becoming aware of the importance of a balance between experimental research and drug development, Black and coworkers developed propranolol, the first clinically effective beta-adrenergic antagonist. The development of this drug not only represented a marked advance in the pharmacotherapy of hypertension, angina pectoris, and arrhythmias, but it also initiated further studies on the physiological role of beta adrenergic receptors by subsequently dividing them into beta- 1 and beta- 2 subtypes. At Black's next position at Smith Kline and French (now GlaxoSmithKline), he introduced a new concept in the treatment of gastric ulcers by producing a drug that blocks histamine $\left(\mathrm{H}_{2}\right)$ receptors.

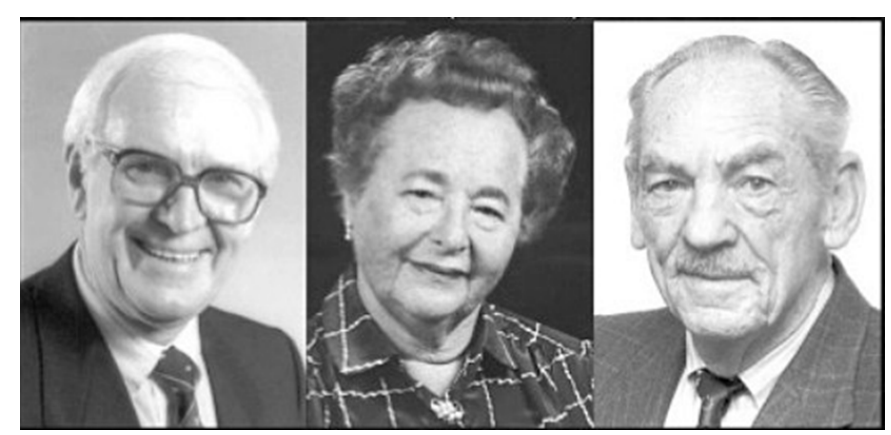

Figure 3. Sir James Black (left), Gertrude Elion (middle), and George Hitchings (right)

Black wanted to escape from commercial constraints in order to have the freedom to pursue his research interests, so he returned to academia by accepting a Chair in Pharmacology at University College London. But, it was not long before John Vane invited Black to join him at Burroughs Wellcome in the United Kingdom in 1977. Black accepted the offer to serve as Director of Therapeutic Research in order to implement ideas he held about the reasons for the success and failure of industrial projects.

During the next six years at Burroughs Wellcome, Black failed to make much progress in his managerial role, but his research, now involving analytical pharmacology, produced a major advance in the description of the functional effects of drugs and their therapeutic potential. A collaboration with Paul Leff, which compared pharmacological data to quantitative models, developed a new framework for categorizing and analyzing drug actions. The most significant tool employed was the operational model, in which the quantitation of agonist activity in one test system enabled the prediction of activity in another system [23]. The principles of this analytical approach have since been employed in drug classification and the mechanisms of drug action [24].

However, despite the fact that Burroughs Wellcome enjoyed an impeccable reputation with regard to its research activity, Black spent seven years dealing with what he felt were traditional and conservative attitudes. For Black, the interplay between corporate commercial needs and personal scientific aspirations provided an ongoing dilemma. The 
perceived counterproductive policies were resolved when a small independent research unit in King's College, London was established for him in 1984 and financially supported by Burroughs Wellcome. It had modern facilities, and together with talented researchers and doctoral students, Black was able to carry out non-profit research with complete independence. Black received his Nobel Prize there in 1988, together with George Hitchings and Gertrude Elion (Figure 3), and remained at Kings College as Professor of Analytical Pharmacology until 1993 when he became Professor Emeritus. In 1988, Black also established the James Black Foundation in the United Kingdom to promote his own vision of pharmacological research [25].

As a fulltime employee of pharmaceutical companies, including Burroughs Wellcome, Black was provided with the independence and resources to be successful. In this way, he was able to offer benefit to both his company and for the good of mankind. Although he derived little personal gain from his discoveries, his strong sense of independence, combined with his dislike for large institutions, caused him to frequently abandon positions whenever he felt the shortsightedness of corporations was obstructing progress in his research. Black's outstanding quality as a researcher can best be described as being able to discover drugs by meticulous structural design based upon known agonists, rather than by random screening.

\section{George Herbert Hitchings (1905-1998) and Gertrude Belle Elion (1918-1999)}

George Hitchings and Gertrude Elion (Figure 3) were the only Nobel Laureates who spent their entire careers at Burroughs Wellcome, even when the company moved from Tuckahoe, New York to North Carolina during a period of sustained research activity. Their investigations covered a span of nearly 40 years and were previously chronicled in some detail [26].

Hitchings received his doctoral degree in Biochemistry from Harvard in 1933, where he studied analytical methods used in physiological studies of purines at a time when little was known about nucleic acid metabolism. After working at several colleges for ten years, Hitchings was hired in 1942 as the only scientist in the Biochemistry Department at Burroughs Wellcome at the Tuckahoe New York facility. Two years later, he recruited Gertrude Elion, a chemist by training, to join his small research group. Elion was then able to leave a rather tedious job of food analyst to join Hitchings when World War II made research positions available for women.

Although up to that time women had difficulty finding jobs in scientific research, Hitchings had no trouble working with women or men from different ethnic backgrounds or religious beliefs, and he encouraged Elion to learn as rapidly and as much as she could. Because she never felt constrained to restrict herself to the subject of chemistry, Elion, who possessed only a Bachelor's and a Master's degree, greatly expanded her scope of knowledge in biochemistry, pharmacology, immunology and virology. As a result, Elion began to take on more and more responsibility by concentrating almost exclusively on purines. Because of residency requirements at Brooklyn Polytechnic University, which would take her away from Burroughs Wellcome, Elion never obtained a formal doctorate. However, she was later awarded an honorary PhD degree from Polytechnic University in 1989 and an honorary SD degree from Harvard in 1998.

As previously noted, drug development had historically been a consequence of random trial and error, as in the case of sulfa drugs for example [27]. Because of the legacy provided by the vision of Henry Wellcome, Hitchings and Elion, like James Black, were free to diverge from this approach by using what then was called "rational drug design [28]." It was based upon the supposition that the understanding of basic biochemical and physiological processes formed the basis for the design and development of drugs. Because their research was based upon the premise that drugs could be designed which were based upon differences in nucleic acid metabolism in normal and abnormal cells, Elion and Hitchings employed specifically designed chemicals to form atypical DNA in abnormal cells which did not affect normal cells. By blocking nucleic acid synthesis, the growth of the abnormal cells would be inhibited. Thus, for example, Hitchings postulated that folic acid deficiency would lead to alterations in the synthesis of purines and pyrimidines and thus DNA.

By 1950, this line of research reaped major dividends when Hitchings and Elion synthesized two antimetabolites, diaminopurine and thioguanine. These substances proved to be effective in the treatment of leukemia. In 1957, further alterations in chemical structure led to the production of azathioprine (AZT). This immunosupressant is now used to prevent the rejection of transplanted organs and to treat rheumatoid arthritis and other autoimmune disorders. However, in the 1980's, because AZT was the primary treatment for AIDS, the United States government allowed Burroughs Wellcome to apply for full patent rights to the drug. As a result, Burroughs Wellcome was able to charge an exorbitant price for AZT to patients with AIDS, despite the fact that the majority of the company was owned by a charitable Foundation, the Wellcome Trust [29,30]. Thus, there was an aspect of the policies of Burroughs Wellcome that dimmed the luster of its legacy.

In 1967 Hitchings became Vice President in charge of research at Burroughs Wellcome, which virtually terminated his involvement in research and redirected his attention to philanthropy. Elion took over his position as Head of the Department of Experimental Therapy. In 1970, the group headed by Hitchings and Elion moved to Research Triangle Park, North Carolina, where they developed the first antiviral drug acyclovir, as well as allopurinol, which is used in the treatment of gout.

Although Henry Wellcome had always been resolute in his commitment to unencumbered biomedical research, Hitchings and Elion did not always find that their efforts were totally supported by management. Hitchings and Elion were subjected to interference by the Head of the Tuckahoe laboratories, William Creasy, who tried to persuade the chemists to work on projects that he favored. Eventually, Creasy relented, realizing that the successes achieved by Hitchings and Elion made it unwise to interfere with their work [31]. In marked contrast, Hitchings and his elite group had key collaboration from the Sloan-Kettering Institute to examine whether purines/pyrimidines possessed anti-neoplastic activity. Moreover, the financial support afforded by Sloan- Kettering enabled Burroughs Wellcome to 
expand and eventually become self-sustaining [32]. Thus, the ability of Hitchings and Elion to test their theories without interference by commercial considerations led to discoveries of important principles for drug treatment resulting in the development of new approaches to pharmacotherapy.

Hitchings and Elion were initially overlooked by the Nobel Committee. One reason perhaps had to do with the fact that the Nobel Prize Committee rarely honors the work of scientists who develop new drugs. However, in 1988 they were awarded the Nobel Prize, some 30 years after most of their major discoveries. Gertrude Elion underscored the profound significance of her work in a review published in Science in 1989, “...chemotherapeutic agents are not only ends in themselves but also serve as tools for unlocking doors and probing Nature's mysteries [33]." When Hitchings retired in 1975, and Elion followed eight years later, another memorable chapter in the history of Burroughs Wellcome came to an end.

\section{John J. Burns (1920-2007) and Allan H. Conney (1930-2013)}

During the same period that Hitchings and Elion were making their invaluable drug discoveries in the Biochemistry Department, John Burns (Figure 4) joined Burroughs Wellcome as Vice-President and Director of Research in 1960. Prior to his arrival at the Tuckahoe New York facility, Burns had worked at the NIH and had provided valuable information about the biosynthesis and metabolism of Vitamin C (ascorbic acid) and the etiology of scurvy [34]. At Burroughs Wellcome, his seminal investigations demonstrated the clinical importance of microsomal enzyme induction. In particular, Burns demonstrated that phenylbutazone is converted in man to two major metabolites, one with anti-rheumatic activity, the other possessing uricosuric actions [35]. The importance of this basic research was underscored by the fact that during the 1960's, the NIH provided financial support for the research being conducted at the Tuckahoe facility.

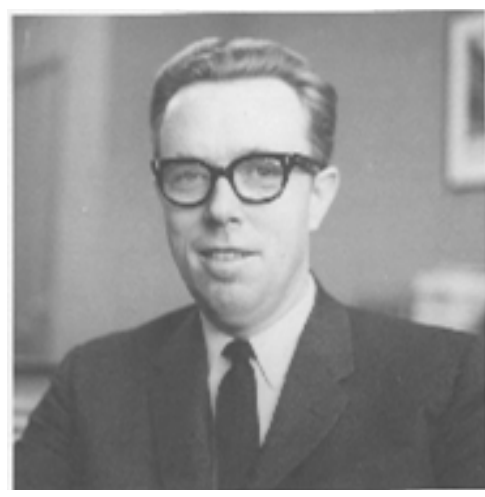

Figure 4. John J. Burns. Courtesy of ASPET)

Coincident with the advent of John Burns, a talented research group was formed in the Department of Biochemistry that included Allan Conney, Ronald Kuntzman, and Richard Welch. Providing fundamental knowledge concerning drug metabolism and its clinical implications, this group was the first to demonstrate the clinical significance of microsomal enzyme induction by showing that chronic administration of several drugs to animals stimulated their metabolism and decreased their toxicity [36]. Also by employing selective inhibitors, they were able to determine whether a drug possessed intrinsic pharmacological activity or owed its activity to a metabolite. This work was of considerable significance in the field of drug metabolism and led to early studies on individual differences in the metabolism of drugs in humans.

John Burns wore many hats as a scientist. While at Burroughs Wellcome, he was also an advisor to a number of biotech companies, a member and officer in a large number of national and international scientific committees, and served as a Visiting Professor of Pharmacology at Albert Einstein College of Medicine. In his capacity as an adjunct faculty member, Burns became thesis advisor to a graduate student, Louis Lemberger. Alfred Gilman, the Chairman of the Pharmacology Department was not enamored of the fact that Lemberger had graduated from a Pharmacy School. Nevertheless, Gilman allowed Lemberger to carry out his doctoral thesis with John Burns. At the time, I was a graduate student at Albert Einstein, and because of the prevailing views I was surprised that one of my fellow students had been allowed to carry out his research at an industrial setting.

Despite the vestiges of prejudice that still existed in academia about drug companies at the time, the legacy generated by Henry Wellcome endured. Subsequently, John Burns encouraged Lemberger to obtain his MD degree and gain further clinical training; and so, Lemberger went on to an outstanding career as Director of Clinical Pharmacology at Eli Lilly in Indianapolis Indiana and as Professor of Pharmacology Medicine and Psychiatry at the Indiana School of Medicine [37]. He was involved in the development of several centrally acting drugs, including Prozac, a commonly prescribed anti-depressant.

John Burns subsequently left Burroughs Wellcome in 1968 to serve as Vice President of Research \& Development at Hoffmann LaRoche, where he helped to develop the famed Roche Institute of Molecular Biology. Adhering to the view that basic research would lead to practical results, Burns supported basic research as much as any pharmaceutical executive. The extensive research conducted by Burns and his colleagues on the metabolic fate and the mechanism of action of drugs provided a fundamental basis for discovering new drugs and improving their therapeutic use. After Dr. Burns retired from Hoffman LaRoche, he served as Adjunct Professor of Pharmacology at Weill Medical College and was scientific advisor to many biotech companies and a member of the National Academy of Sciences. However, his work at Burroughs Wellcome proved to be seminal.

The Biochemistry group led by Allan Conney (Figure 5) was also involved in investigating other areas of drug metabolism, including cytochrome P-450, a family of enzymes responsible for the biotransformation of many medications, toxic substances, and environmental chemicals [38,39]. Conney's work provided the molecular basis for understanding how drugs induce tolerance and environmental chemicals produce mutagenesis and carcinogenesis.

Much of Conney's career was spent in the pharmaceutical industry, first at Burroughs Wellcome and then at Hoffman-LaRoche, 
where he rejoined John Burns. Further recognition of Conney's work came from a prestigious faculty appointment at Rutgers University in 1987, where he established the Department of Chemical Biology and founded the Laboratory for Cancer Research. At Rutgers University, Conney continued to carry out research mainly on cancer prevention [40]. His contributions were recognized by his election to the National Academy of Sciences in 1982, and as President of the American Society for Pharmacology and Experimental Therapeutics (ASPET) (1983-1984). During the years 1965-1978, Dr. Conney was among the 40 most cited scientists in the field of pharmacology.

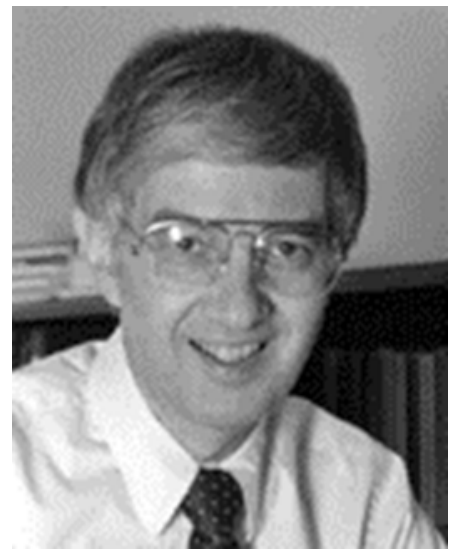

Figure 5. Allan Conney

It was fitting that we end this article by recounting the work of Allan Conney, because it defines a gifted scientist who readily bridged the gap between industry and academia. The now entrenched alliances between academia and industry provided another important advance in mankind's search for more effective medications. Once again, it took some time, but the overall lesson learned by scientists is that forward thinking and cooperation will always trump unfounded biases.

\section{Epilogue}

The research laboratories that Henry Wellcome set up first in the United Kingdom in 1880 and then throughout the world employed elite researchers who performed rational and outstanding biomedical research. As a result, the company set the stage for the advent of Pharmacology as an established biomedical discipline. Although the Burroughs Wellcome Research Institute is no longer a functional entity, having been assimilated by Smith/Kline/Glaxo in the 1980's, the research arm of the company provided the path for academicians to join forces with industrial companies to produce medications that have extended human life and reduced human suffering.

\section{References}

1. Church R, Tansey EM (2007) Burroughs Wellcome and Company: Knowledge, Trust, Profit and the Transformation of the British Pharmaceutical Industry Crucible Books, Lancaster UK, Pg No :1880-1940

2. Bailey $\mathrm{P}(2008)$ The birth and growth of Burroughs-Wellcome \& Co. The Wellcome Trust, 2008.

3. James RR. Henry Wellcome (1994) Hodder \& Stoughton, London, United Kingdom.

4. Bailey P (2008) Henry Wellcome's Physiological and Chemical Research Laboratories. Wellcome Trust. 2008. http//www.wellcome.ac.uk./About-us/ History/WTX052313.htm.
5. Dale HH (1938) An autobiographical sketch. Perspec. Biol. Med. 1938; 1: 128-130. See also Dale HH. Introduction; In: Adventures in Physiology. London. Pergamon Press. pp x-xvi.

6. Dale HH (1906) On some physiological actions of ergot. J Physiol 34: 163-206. [crossref]

7. Elliott TR (1905) The action of adrenalin. J Physiol 32: 401-467. [crossref]

8. Barger G, Dale HH (1910) Chemical structure and sympathomimetic action of amines. J Physiol 41: 19-59. [crossref]

9. Dale HH (1914) The action of certain esters and ethers of choline, and their relation to muscarine. J. Pharmacol. Exp. Ther. 6: 147-190.

10. Dale HH. (op cit. Ref 7). pg. 189.

11. Sánchez García P (2010) [The neurotransmision from the other side]. An R Acad Nac Med (Madr) 127: 257-268. [crossref]

12. Moncada S (2006) Sir John Robert Vane: 29 March 1927 - 19 November 2004. Biogr Mem Fellows R Soc 52: 401-411. [crossref]

13. Vane JR (1971) Inhibition of prostaglandin synthesis as a mechanism of action for aspirin-like drugs. Nat New Biol 231: 232-235. [crossref]

14. John R. Vane- Biographical. Nobelprize.org. Nobel Media AB 2014. Web. 7 Apr 2016.

15. Flower R (2006) John Vane. A Biographical Sketch. In Memory of Sir John Vane. (Nistico, G. McGiff J \& Born G. Editors); 2006; Roma; Exorma. pp. 53-55.

16. Moncada S (1982) Eighth Gaddum Memorial Lecture. Biological importance of prostacyclin. Br. J. Pharmacol. 76: 3-31.

17. Obituary (2004) Sir John Vane. The Telegraph.

18. Howlett R (1998) Nobel award stirs up debate on nitric oxide breakthrough. Nature 395: 625-626. [crossref]

19. Vane JR (1994) The Croonian Lecture, 1993. The endothelium: maestro of the blood circulation. Philos Trans R Soc Lond B Biol Sci 343: 225-246. [crossref]

20. Moncada S (2006) Sir John Robert Vane: 29 March 1927 - 19 November 2004. Biogr Mem Fellows R Soc 52: 401-411. [crossref]

21. Braunwald E (2010) Sir James W. Black MD, FRS. In Memoriam. Circ. Res. 107: 3-5.

22. Black's autobiographical sketch can be found in: Les Prix Nobel. The Nobel Prizes 1988; Editor Tore Frangsmyr. (Nobel Foundation) 1989. Stockholm.

23. Black JW, Leff P (1983) Operational models of pharmacological agonism. Proc $R$ Soc Lond B Biol Sci 220: 141-162. [crossref]

24. Kenakin T, Christopoulos A (2011) Analytical pharmacology: the impact of numbers on pharmacology. Trends Pharmacol Sci 32: 189-196. [crossref]

25. Wright $\mathrm{P}$ (2010) Sir James Black obituary: Nobel prizewinning pharmacologist who invented new drugs such as beta-blockers. The Guardian.

26. Rubin RP. A brief history of great discoveries in pharmacology. Pharmacol. Rev. 2007; 59: pp. 311-314.

27. Rubin RP (op. cit. Ref. 23). pp. 315-318.

28. Turney J (2009) Rational drug design: Gertrude Elion and George Hitchings. Wellcome Trust. London, England.

29. http://www.nytimes.com/1989/08/28/opinion/azt-s-inhuman-cost.html

30. Emmons WM (1991) Burroughs Wellcome and AZT. (A): Faculty \& Research. Harvard Business School Case 792-004.

31. Turney J. (op. cit. Ref. 25).

32. George H. Hitchings- Biographical. The Nobel Prize in Physiology or Medicine 1988. From Les Prix Nobel; The Nobel Prize 1988. Editor Tore Frangsmyr [Nobel Foundation]. Stockholm.1988.

33. Elion G The purine path to chemotherapy. Science. 1989; 244: pg. 46.

34. Kuntzman R and Conney A (2008) Dr. John J. Burns. 1920-2007. Obituary. Neuropsychopharmacology. 33: 458-459.

35. Kuntzman R and Conney A. (op. cit. Ref. 34). pg. 458.

36. Burns JJ (1964) Editorial. Implications of enzyme induction for drug therapy. Amer. J. Med. 37: 327-331.

37. Albert Einstein College of Medicine (1989) Alumni. Louis Lemberger M.D, PH.D. Distinguished Alumnus.

38. Conney AH (1967) Pharmacological implications of microsomal enzyme induction. Pharmacol. Rev. 19: 317-366.

39. Conney AH (2003) Induction of drug-metabolizing enzymes: a path to the discovery of multiple cytochromes P450. Annu Rev Pharmacol Toxicol 43: 1-30. [crossref]

40. Yang CS Suh N Stoner G, Dong, Z and Surh Y-J. Allan H (2013) Conney: In Memoriam (1930-2013). Cancer Prev. Res. 6: 1376-1377.

\section{Citation:}

Rubin RP (2018) Burroughs Wellcome: The Seminal Link between Academia and the Pharmaceutical Industry. Internal Med Res Open J Volume 3(4): 1-6. 